\title{
Hydraulic retention time on vinasse stabilisation with limestone in the acidogenic phase of anaerobic digestion
}

\author{
Ismael Plácido Tomielis ${ }^{1}$ Sheyla Thays Vieira Barcelos ${ }^{1}$ Marney Pascoli Cereda ${ }^{*}$
} ${ }^{1}$ Centro de Tecnologia e Estudo do Agronegócio (CeTeAgro), Universidade Católica Dom Bosco (UCDB), 79117-900, Campo Grande, MS,
Brasil. E-mail: cereda@ucdb.br. "Corresponding author.

\begin{abstract}
The main problem in anaerobic digestion of low-protein residues is the instability caused acidity. The use of limestone at the same time as a neutralizing agent and support material is innovative because stones wear allows the slow release of the calcium carbonate thereby eliminating dispersers. Free calcium content in the system was measured in two plug flow reactors filled with vinasse at initial $p H$ of 4.50. The proportion of 1.8 tonnes of limestone per $m^{3}$ of vinasse was evaluated at the Hydraulic Retention Times (HRT) of 24, 48, 72, 96 and 120 hours, allowing stabilisation at 96 hours. The ratio of Volatile Acids/Total Alkalinity (VA/TA) ranged from 0.2 to 0.4 and the pH reached 7.0, at the HRT of 120 hours. Increasing the HRT also increased the volatile total solids (VTS) and fixed total solids (TFS) in a similar profile to the measured free calcium content, but calcium remained at the appropriate level of 100 to $250 \mathrm{mg}^{-1}$. The proportion of limestone/vinasse was adequate to ensure stabilisation, but it is not recommended to reduce the HRT below 96 hours due to the risk of compromising the stability of the anaerobic system.
\end{abstract}

Key words: hydraulic retention time, sugarcane mill, free calcium, VA/TA.

Tempo de retenção hidráulica em vinhaça estabilizada com calcário na fase acidogênica da digestão anaeróbia

RESUMO: O maior problema na digestão anaeróbia de resíduos de baixo teor de proteína é a instabilidade por acidez. O uso de calcário ao mesmo tempo como agente neutralizador e material suporte é inovador porque permite eliminar o dosador pois o desgaste das pedras permite a liberação lenta do carbonato de cálcio. O teor de cálcio livre no sistema foi medido em dois reatores tipo Plug flow, preenchidos com vinhaça com pH inicial de 4,50. A proporção de 1,8 toneladas de calcário por $m^{3}$ de vinhaça foi avaliada com os Tempos de Retenção Hidráulica (TRH) de 24, 48, 72, 96 e 120 horas, permitindo a estabilização em 96 horas. Com um TRH de 120 horas, a relação de Ácidos Voláteis/Alcalinidade (AV/AC) variou de 0,2 à 0,4 e o pH atingiu 7,0. Aumentando o TRH também aumentaram os sólidos voláteis totais (SVT) e sólidos totais fixos (STF) em um perfil semelhante ao teor de cálcio livre medido, mas mantendo níveis adequados de 100 a $250 \mathrm{mg} \mathrm{L}^{-1}$. A proporção de calcário/vinhaça mostrou-se adequada para garantir a estabilização, mas não se recomenda a redução do TRH abaixo de 96 horas devido ao risco de comprometer a estabilidade do sistema anaeróbio. Palavras-chave: tempo de retenção hidráulica, usina de cana-de-açúcar, cálcio livre, AV/TA.

\section{INTRODUCTION}

The vinasse is generated in the distillation process of ethanol at a rate of 10 to 14 litres per each alcohol litre (SILVA et al., 2007) and only in the period $2016 / 2017$ Brazil produced $632,879,440$ tons of sugarcane resulting $26,685,074 \mathrm{~m}^{3}$ of ethanol, of which $15,931,559 \mathrm{~m}^{3}$ of hydrous ethanol and $10,753,515 \mathrm{~m}^{3}$ of ethanol anhydrous (MAPA, 2017). For these data the vinasse produced in this same period would be from $266,850,740 \mathrm{~m}^{3}$ to $373,591,036 \mathrm{~m}^{3}$ of vinasse.

Vinasse application as a fertilizer on sugarcane crops around the sugarcane mill or distillery is already sufficient to prove that it is not only a residue, but one product that presents some great applications, such as hydrogen and methane production in two-stage reactors (FU et al., 2017), the production of hydrogen (FUESS et al., 2016) or also the microbial biomass for animal feed supplementation (PIRES et al., 2016). FUESS et al. (2017) considered that anaerobic digestion is the most suitable approach for the management of vinasse in sugarcane distilleries because both environmental adequacy and bioenergy recovery are achieved through biogas production. It must not be forgotten the environmental concerns associated with irrigation vinasse (FUESS \& GARCIA, 2014). However, the anaerobic digestion is little used in Brazilians sugarcane mills, but research shows that the bioprocess can even improve the quality of the vinasse to be used as a fertilizer. 
Removing of organic matter by anaerobic digestion may generate biogas, increasing the $\mathrm{pH}$ and maintaining the mineral composition for use as a fertilizer at the same time (RIBAS et al., 2010). Biogas produced by anaerobic digestion can be used to generate electricity by means of stationary machines for the industry power supply or be burned in the boiler, saving bagasse. It can also be used as fuel in the plant's truck and tractor fleet, but first, it needs to be mixed with diesel due to the fact that Brazil does not possess yet high power engines fully adapted only for biogas. Gas produced in anaerobic digestion was highly valued in the exchange for carbon credits, which is valid not only for biogas but also for the process (MORAES et al., 2014), but for this valorization, it is necessary that the anaerobic digestion is efficient and not expensive. One of the main factors that may influence the anaerobic digestion efficiency is $\mathrm{pH}$ stability. The optimal growth of methanogenic archaea occurs at $\mathrm{pH}$ between 6.6 and 7.6 (RITTMAN \& MACCARTY, 2001).

The $\mathrm{pH}$ depends greatly on the buffering power of the substrate, which is high when there is a high protein content. Low protein content presented by vinasse and wastewater from the starch extraction industry causes $\mathrm{pH}$ instability. This instability occurs in these liquid wastes when a small variation of the acidity produced by acidogenic bacteria results in a large variation in the $\mathrm{pH}$ value that leaves the favourable range for the balance of the microorganisms in the anaerobic digestion (RIBAS et al., 2010; OLIVEIRA-JUNIOR et al., 2012). As a consequence, the production of biogas becomes unstable and may be disrupted.

The anaerobic digestion instability can be controlled by physical separation in a two-stage system. Despite the high cost of building one more reactor, this process yields more biogas, as reported by FERRAZ JÚNIOR et al. (2016) who obtained 25.7\% more biogas when comparing to biogas produced by a single-stage system. Lately, FUESS et al., (2017) confirmed previous results simulated for full-scale, and e results confirmed that phase separation is economically feasible when scaling up. In spite of the higher capital and operating costs in such schemes, the estimated biogas and electricity production costs reached equivalent or lower values compared to those of a single-phase. However, authors pointed out that the alkalizing strategy used is a factor to be considered for this result.

The use of support materials is another way of avoiding the effect of instability, what happens mainly because of the microorganisms' ability to remain adhered to the surface of these materials and consequently, turning them more resistant to the medium changes. Various support materials are cited in the literature for the purpose of working as support for biomass attachment; among them, the expanded clay, charcoal, porous ceramic, and the low-density polyethylene are the most common (FERRAZ JÚNIOR et al. 2015).

Testing several alkalizing agents, FUESS et al. (2017) found out that the use of $\mathrm{NaHCO}_{3}$ provides better conditions for methanogens than stronger alkaline compounds, such as $\mathrm{NaOH}$, but its use results in higher costs. These authors also recommended experimental studies on the optimization of $\mathrm{NaHCO}_{3}$ to increase the economic competitiveness of this type of alkalizing strategy in full-scale anaerobic digestion plants.

Among the alkalizing agents, limestone is still poorly studied but has industrial applications (SUN et al., 2010) in wet flue gas desulfurization process carried out using a model limestonehydrochloric acid reaction system. The authors remembered that the main content in the limestone slurry is particles of $\mathrm{CaCO}_{3}$, which could dissolve and react with the dissolved $\mathrm{SO}_{2}$ and $\mathrm{O}_{2}$ to produce $\mathrm{CaSO}_{4} \cdot 2 \mathrm{H}_{2} \mathrm{O}$, an insoluble particle. The same authors also reported the limestone composition. RAU et al. (2007) explored the limestone use as a $\mathrm{CO}_{2}$ capture. For them, about $76 \%$ of limestone extracted in the world are used for construction, $19 \%$ for chemical and metallurgical applications, and the remaining for miscellaneous uses, representing more than $20 \%$ of the current US crushed limestone production and provide an inexpensive or free source of carbonate.

The use of neutralizing agents is a very effective way to reduce acidity, in addition to the fact that it also acts favouring the microbial process. When carbonates are used as alkalizing agents they increase insoluble particles that can promote granulation in the reactor, which reduces the impact of acidity on the methanogenic bacteria (TORRES et al., 2008). Calcium plays several beneficial aspects in the multiplication of cells and development of the granules in anaerobic digestion. Conversely, the presence of a high quantity of calcium could damage the environment required for maintenance of the granular structure or the bacterial activity. The amount of calcium that may precipitate in each reactor varied with the influent calcium concentration; the higher the influent calcium concentration, the higher the calcium precipitated is (YU, et al., 2001). 
Limestone is an efficient neutralizer agent, considered inexpensive and easy to be acquired. The limestone belongs to the group of alkalizing agents that forms bicarbonate alkalinity directly (RAU et al., 2007). Stabilisation of vinasse in the acidogenic phase with limestone as power may be suitable for the use in rural areas because limestone is widely used in agriculture as a soil-neutralizing agent. It is a source of calcium that is soluble only in an acid medium but after the reaction may be insoluble and deposited (SUN et al., 2010).

The first references to the use of limestone as a neutralizing agent and support material at the same time are from RIBAS \& CEREDA (2003) and RIBAS et al. (2010), both for cassava wastewater from starch extraction. Another advantage is that limestone solubilisation occurs naturally with the acidity increase and thus, does not use dispersers. However, the good results obtained may also increase the concentration of free calcium in the reactor. So this article evaluated the concentration of calcium as the effect of the variation of hydraulic residence time in a plug flow type reactor fed with raw vinasse.

\section{MATERIALS AND METHODS}

The experiment was conducted at the coordinates $20^{\circ} 26^{\prime} 34$ south latitude, $54^{\circ} 38^{\prime} 47$ west longitude, and at 630 meters altitude, from August 2014 to August 2015 with the vinasse obtained from the sugarcane juice collected at a local distillery. For the experiment, 100 litres of vinasse were transported in plastic containers and stored in two-litre plastic bottles at $-20^{\circ} \mathrm{C}$ and then the vinasse was cooled and stored at refrigerator temperature $\left(4^{\circ} \mathrm{C}\right)$ when necessary. Vinasse was characterized (Table 1) but the authors used the enterprise report for the limestone composition.

\section{Acidogenic phase}

It was used 2 plug flow reactors (duplicate) only in the acidogenic phase as a continuous acidogenic packed-bed reactor. Each one was $450 \mathrm{~mm}$ high and $200 \mathrm{~mm}$ in diameter, providing a total capacity of ten litres. Each reactor received $7,650 \mathrm{~kg}$ of dolomitic limestone with granulometry between $50 \mathrm{~mm}$ and $20 \mathrm{~mm}$ (OLIVEIRA-JUNIOR et al., 2012). The top of the two reactors was closed with an acrylic dome, which was provided with an outlet to allow the gas to escape through a pipe to be captured in an acidified saline solution and measured. The working volume of 4.56 litres was filled with sufficient vinasse to immerse the limestone to act as both alkalizing agent and support material. This proportion was previously established by OLIVEIRA-JUNIOR et al., (2012) as the best proportion and would be equivalent in practice to 1.8 tonnes of limestone by each $\mathrm{m}^{3}$ of vinasse. Dolomitic limestone was purchased from a local industry with a final price of U.S. \$69 per tonne and presented an average rate of $30 \%$ of calcium.

\section{Operating conditions}

Reactors were continuously fed with vinasse by a storage tank sufficient for a period of 24 hours, which was located above the reactor. Feed tank was provided with a float system to maintain constant pressure. Hydraulic retention time (HRT) was set at 24, 48, 72, 96 and 120 hours and monitored three times, before being changed. At each HRT, samples in three replications were collected for monitoring analysis.

\section{Monitoring analysis}

The analyses were conducted as described by APHA-AWWA-WPCF (2012) and included $\mathrm{pH}$ and Chemical Oxygen Demand (COD), total alkalinity (TA) and volatile acidity (VA). Mineral characterization of vinasse was carried out using nitropercloric digestion with readings in an atomic absorption spectrum, as described by MALAVOLTA (1992). At the end of each HRT, samples collected were analyzed for Total Volatile Solids (TVS) and Total Fixed Solids (TFS). For the evaluation of system steady-state, samples of $50 \mathrm{ml}$ were adjusted to $\mathrm{pH} 7.5$ and incubated at $30^{\circ} \mathrm{C}$ for 48 hours, when the $\mathrm{pH}$ was once more verified and adjusted to 7.5 (TORRES et al., 2008). The criteria used for establishing the end of stabilisation was set when the $\mathrm{pH}$ value had not varied more than 0.1 when measured after 72 hours, as described by RIBAS \& CEREDA (2003).

\section{Data analysis}

Results were expressed as means and standard deviation of three replicates. They were also submitted to a simple regression analysis, which allowed the establishment of curves to adjust the results and predict thems beyond the maximum time evaluated in the experiment. All equations obtained are inserted in the text. The Mean and Standard Deviation $(\sigma)$ were established with the results of the normal distribution. All means were compared by Tukey test at 5\% of probability using the software Statistica 7.0.

\section{RESULTS AND DISCUSSION}

Characterization of the vinasse used in the experiments is presented in table 1. Results of ELIA 
Table 1 - Physicochemical characterization of vinasse sample from Mato Grosso do Sul, compared to the literature (ELIA NETO; NAKAHODO, 1995).

\begin{tabular}{|c|c|c|c|}
\hline Characterization & Units & Elia Neto, (1995) & Vinasse sample \\
\hline $\mathrm{pH}$ & {$\left[\mathrm{H}^{+}\right]$} & 4.2 & 4.5 \\
\hline Temperature & $\left({ }^{\circ} \mathrm{C}\right)$ & 89 & 70 \\
\hline Chemical Oxygen Demand & $\left(\mathrm{mg} \mathrm{O}_{2} \mathrm{l}^{-1}\right)$ & 28450 & 106 \\
\hline Total Nitrogen & $\left(\mathrm{g} \mathrm{l}^{-1} \mathrm{~N}\right)$ & 357 & 0.18 \\
\hline Total Solids (TS) & $\left(\mathrm{mg} \mathrm{l}^{-1}\right)$ & 25155 & 10612 \\
\hline Total Fixed Solids (TFS) & $\left(\mathrm{mg} \mathrm{l}^{-1}\right)$ & 11872 & 3714 \\
\hline Total Volatile Solids (TVS) & $\left(\mathrm{mg} \mathrm{l}^{-1}\right)$ & 6580 & 6898 \\
\hline Calcium & $\left(\mathrm{mg} \mathrm{l}^{-1} \mathrm{CaO}\right)$ & 515 & 0.015 \\
\hline Copper & $\left(\mathrm{g} \mathrm{l}^{-1} \mathrm{CuO}\right)$ & 1.20 & 0.14 \\
\hline Iron & $\left(\mathrm{g} \mathrm{l}^{-1} \mathrm{Fe}_{2} \mathrm{O}_{3}\right)$ & 25.2 & 57.62 \\
\hline Phosphorus & $\left(\mathrm{g} \mathrm{l}^{-1} \mathrm{P}_{2} \mathrm{O}_{4}\right)$ & 60.4 & 0.001 \\
\hline Magnesium & $\left(\mathrm{m} \mathrm{l}^{-1} \mathrm{MgO}\right)$ & 226 & 0.004 \\
\hline Manganese & $\left(\mathrm{m} \mathrm{l}^{-1} \mathrm{MnO}\right)$ & 4.8 & 0.81 \\
\hline Potassiun & $\left(\mathrm{mg} \mathrm{l}^{-1} \mathrm{~K}_{2} \mathrm{O}\right)$ & 2035 & 0.01 \\
\hline Zinc & $\left(\mathrm{mg} \mathrm{l}^{-1} \mathrm{ZnO}\right)$ & 1.7 & 0.81 \\
\hline
\end{tabular}

Mean values of physicochemical characterization of vinasse (average of 64 samples) and values reported for the vinasse used in this study from a distillery in the state of Mato Grosso do Sul, Brazil (average of 3 analyses).

NETO (1995) correspond to a complete revision of the results reported in the literature. The values showed variation if compared to this literature, which is quite common for this type of product (RIBAS et al., 2010). Table 2 shows the influence of HRT variation on $\mathrm{pH}$ and VA/TA ratio in the reactors feed with limestone used as a support material and neutralizing agent and its significance.

\section{Acidity control}

The $\mathrm{pH}$ variation with HRT showed that the initial value of 6.86 dropped at 72 hours, representing its lowest value and then, increased significantly to
$\mathrm{pH} 7.0$ at the end of the experiment, not differing from the initial one. This variation is represented by the equation $y=-0.0003 \times 2+0.0386 x+5.0614\left(r^{2}=0.44\right)$.

The VA/TA ratio was stable with the HRT variation since the values reported were not different from each other. The equation $y=0,0003 x^{2}+0.0386 x+0.41$ represents the VA/ TA variation with the high correlation coefficient $\left(r^{2}=0.97\right)$. Results showed that the acids formed were readily neutralized and did not influence $\mathrm{pH}$ and could be an answer to the difficulties reported by FUESS et al. (2017) as limiting factor for the scale-up of the anaerobic digestion in the sugarcane mills.

Table 2 - Variation of pH, VA/TA, Total Fixed Solids, Total Volatile Solids and Calcium as a function of HRT (hours) in a reactor with limestone as a support material and neutralizing agent, feed with vinasse (Average 3 replications).

\begin{tabular}{|c|c|c|c|c|c|}
\hline \multirow[t]{2}{*}{ Analysis } & \multirow[b]{2}{*}{24} & \multicolumn{3}{|c|}{--Hydraulic Retention Time (hours) } & \multirow[b]{2}{*}{120} \\
\hline & & 48 & 72 & 96 & \\
\hline $\mathrm{pH}\left[\mathrm{H}^{+}\right]$ & $6.86 \pm 0.04 a$ & $6.42 \pm 0.09 b$ & $5.82 \pm 0.06 \mathrm{c}$ & $6.41 \pm 0.04 b$ & $7.00 \pm 0.0 \mathrm{a}$ \\
\hline VA/TA & $0.35 \pm 0.01 \mathrm{a}$ & $0.30 \pm 0.02 \mathrm{a}$ & $0.30 \pm 0.01 \mathrm{a}$ & $0.32 \pm 0.01 \mathrm{a}$ & $0.36 \pm 0.02 \mathrm{a}$ \\
\hline $\operatorname{TVS}\left(\mathrm{mg} \mathrm{l}^{-1}\right)$ & $0.9 \pm 0.07 \mathrm{c}$ & $147.0 \pm 3.54 \mathrm{c}$ & $2803.0 \pm 28.28 b$ & $3095.0 \pm 47.1 \mathrm{ab}$ & $4374.0 \pm 19.8 \mathrm{a}$ \\
\hline TFS $\left(\mathrm{mg} \mathrm{l}^{-1}\right)$ & $0.7 \pm 0.07 \mathrm{e}$ & $134,0 \pm 4.95 \mathrm{~d}$ & $2708.0 \pm 14.14 \mathrm{c}$ & $3313.0 \pm 15.5 b$ & $4443.0 \pm 12.0 \mathrm{a}$ \\
\hline Calcium $\left(\mathrm{mg} \mathrm{l}^{-1}\right)$ & $0.1 \pm 0.07 \mathrm{e}$ & $34.0 \pm 1.41 \mathrm{~d}$ & $190.5 \pm 3.54 \mathrm{c}$ & $204.4 \pm 4.53 b$ & $221.4 \pm 6.36 \mathrm{a}$ \\
\hline
\end{tabular}

Legend: VA: Volatile Acidity; TA: Total Alkalinity; TVS: Total Volatile Solids; TFS: Total Fixed Solids. The same lowercase letters in the lines do not differ from each other at the $5 \%$ level of significance by Tukey test. 
With the use of limestone, the $\mathrm{pH}$ and the VA/TA was maintained at appropriate values without the need for a disperser, since the neutralization is made during the formation of the acids. In this case, the costs may be reduced in either the cases of one or two phases.

However, these results confirm the HRT of 4 days reported by RIBAS \& CEREDA (2003) when cassava wastewater is stabilized in the acidogenic phase also using limestone, with a VA/ TA ratio of 1.2; however, with an HRT of 96 hours (4 days). In this experiment (Table 2) the HRT next to 100 hours was close to that reported by RIBAS \& CEREDA (2003) and OLIVEIRA-JUNIOR et al. (2012). At this specific HRT, OLIVEIRA et al., (2012) found out a $\mathrm{pH} 6.0$ for vinasse stabilisation with limestone with the VA/TA ratio variation lower than 0.1 for the same ratio used in the present experiment (1.8-tonnes of limestone $\mathrm{m}^{-3}$ of vinasse), with the $\mathrm{pH}$ ranging from 7.5 to 8.0 and the VA/TA ratio from 0.6 to 0.8 .

All results for operating conditions are considered as satisfactory when comparing them with the information obtained by BEUX et al. (2007), who pointed out that for wastewater with low buffer capacity the VA/TA should range from 0.06 to 0.20 , or from 0.7 to 1.3 , with a $\mathrm{pH}$ range of 7.6 to 8.2.

As the neutralization of the acids formed in the acidogenic phase of the anaerobic digestion of the vinasse occurs due to the wear of the limestone, the increase of the solids fixed in the effluent was expected, mainly by the insolubilization of calcium carbonate.

Table 2 shows that the Total Volatile Solids increased in a logarithmic relation represented in the equation $y=2133.31 \ln (x)-501.69\left(r^{2}=0.87\right)$, with the occurring to the Total Fixed Solids ( $y=2201.71$ $\left.\ln (\mathrm{x}) 7488.8, \mathrm{r}^{2}=0.87\right)$, which presented significant increases in each time evaluated.

The increase in the HRT may be explained by the increase in the calcium concentration in the treated vinasse, mainly due to the gradual solubilization of the dolomitic limestone and the neutralization of the organic acids that were formed, releasing $\mathrm{Ca}^{+2}$ ions. Since calcium is insoluble it appears as TFS, but it also appears in the biomass, where it would be represented as TVS. Table 2 also shows that variation of the free calcium content in the stabilized vinasse ranged from 0.015 to more than $200.0 \mathrm{mg} \mathrm{Ca}^{+2} \mathrm{1}^{-1}$, following the same logarithmic equation of TFS and TVS ( $\mathrm{Y}=150.39 \mathrm{ln}$ $\left.(x)=501.69\left(r^{2}=0.92\right)\right)$. This equation allows us to evaluate that at an HRT longer than 100 hours with stabilisation by limestone, the calcium content is probably between 100 and $250 \mathrm{mg} \mathrm{Ca}^{+2} \mathrm{l}^{-1}$.

ZOUTBERG \& EKER, (1999) observed a distinct improvement in the biomass settle ability and specific activity after replacing $\mathrm{NaHCO}_{3}$ by $\mathrm{Ca}(\mathrm{OH})_{2}$ as a neutralizing agent in the treatment of wastewater from potato processing and, HULSHOFF POL (2004) obtained similar results with the treatment of vinasse.

Calcium was measured in the vinasse effluent treated with limestone, but it can also be retained in the biomass as reported by YU et al. (2001), who emphasized the role of calcium in anaerobic digestion promoting stability as a positive effect on the granulation of sludge.

Results made it possible to say that even with a very long HRT, the calcium content in the reactor would remain at a constant level. KUGELMAN et al. (1965) and YU et. al. (2001) found out that the optimum calcium concentration for the methanation of acetic acid is $200 \mathrm{mg} \mathrm{Ca}^{+2}$ $1^{-1}$ with the limit ranging from 2000 to $5000 \mathrm{mg}$ $\mathrm{Ca}^{+2} 1^{-1}$. Operating a methanogenic reactor for cassava wastewater stabilised with limestone in the acidogenic phase, RIBAS et al. (2010) detected $2,220.0 \mathrm{mg} \mathrm{l}^{-1}$ of $\mathrm{Ca}^{+2}$. Hence, with these characteristics, it is possible to confirm that the cost of the limestone used with a final price of U.S. $\$ 69 \mathrm{~m}^{-3}$ is much lower than the costs reported by TORRES et al. (2008) for hydrated lime (Ca $(\mathrm{OH})_{2}$ ), which was about U.S.\$320 $\mathrm{m}^{-3}$.

The calcium content reported in the present experiment reassure us about the observations of FUESS et al. (2017), who reported that in addition to the economic aspects of dosing $\mathrm{NaHCO}_{3}$ and $\mathrm{NaOH}$ as alkalizing agents for sugarcane vinasse, some environmental implications of the alkalinization process should be considered, in particular regarding to the role of sodium ions $\left(\mathrm{Na}^{+}\right)$in soils ferti-irrigated with biodigested vinasse, because the $\mathrm{Na}^{+}$ions act as highly dispersive agents, when hydrated, by disrupting the stable aggregates of the soil, which may drastically reduce water infiltration due to clogging.

\section{CONCLUSION}

The vinasse used in the experiments presented lower values than the average composition reported in the literature. The main differences reported are for COD, phosphorus, and potassium.

The data obtained in the present study confirmed previous research, which selected the ratio 
of 1.8-ton limestone $/ \mathrm{m}^{3}$ of vinasse as allowing the vinasse to stabilize at the appropriate $\mathrm{pH}$ level and VA/ AT ratio. However, $t$ results showed that a reduction in the HRT for 4 days (96 hours) is not recommended; otherwise, the instability of the anaerobic system may occur. Under these selected conditions, the range of free calcium remained at appropriate levels in the treated vinasse, near $200 \mathrm{mg} \mathrm{Ca}^{+2} \mathrm{l}^{-1}$, which favoured the granule formation of the anaerobic system without harming the process.

\section{REFERENCES}

APHA; AWWA; WPCF. Standard methods for the examination of water and wastewater. Washington: American Public Health Association, 2012. 1496p.

BEUX, S. et al. Effect of temperature on two-phase anaerobic reactors treating slaughterhouse wastewater. Brazilian Archives of Biology and Technology, v.50, n.6, p.1061-1072, 2007. Available from: <http://www.scielo.br/scielo.php?script=sci_artt ext\&pid=S1516-89132007000700017>. Acessed: Nov. 20, 2016. doi: 10.1590/S1516-89132007000700017.

ELIA NETO, A.; NAKAHODO, T. Caracterização físico-química da vinhaça. Piracicaba: Centro de Tecnologia Canavieira, 1995. 26p. (Projeto $n^{\circ} 9500278$. Relatório Técnico da Seção de Tecnologia de Tratamento de Águas do Centro de Tecnologia Coopersucar).

FERRAZ JÚNIOR, A.D.N. et al. Mesophilic hydrogen production in acidogenic packed-bed reactors (APBR) using raw sugarcane vinasse as substrate: influence of support materials. Anaerobe, v.34, p.94-105, 2015. Available from: <http://www.sciencedirect. com/science/article/pii/S1075996415300093>. Acessed: Nov. 19, 2016. doi: 10.1016/j.anaerobe.2015.04.008.

FERRAZ JÚNIOR, A.D.N. et al. Thermophilic anaerobic digestion of raw sugarcane vinasse. Renewable Energy, v.89, p.245-252, 2016. Available from: <http://www.sciencedirect.com/science/ article/pii/S0960148115304808>. Acessed: Oct. 12, 2016. doi: 10.1016/j.renene.2015.11.064.

FU, S.-F. et al. Hydrogen and methane production from vinasse using two-stage anaerobic digestion. Process Safety and Environmental Protection, v.1, n.2, p.81-86, 2017. Available from: <http://www.sciencedirect.com/science/ article/pii/S0957582017300290>. Acessed: Sept. 05, 2016. doi: 10.1016/j.psep.2017.01.024.

FUESS, L.T. et al. Designing full-scale biodigestion plants for the treatment of vinasse in sugarcane biorefineries: how phase separation and alkalinization impact biogas and electricity production costs? Chemical Engineering Research and Desing, v.119, p.209-220, 2017. Available from: <http:/www.sciencedirect. com/science/article/pii/S0263876217300758>. Acessed: Nov. 26, 2016. doi: 10.1016/j.cherd.2017.01.023.

FUESS, L.T. et al. Operational strategies for long-term biohydrogen production from sugarcane stillage in a continuous acidogenic packed-bed reactor. International Journal of Hydrogen Energy, v.41, n.19, p.8132-8145, 2016. Available from: <http://www. sciencedirect.com/science/article/pii/S036031991502741X $>$. Acssessed: Nov. 14, 2016. doi: 10.1016/j.ijhydene.2015.10.143.
FUESS, L.T., GARCIA, M.L. Implications of stillage land disposal: a critical review on the impacts of fertigation. Journal Environ Management, v.145, p.210-229, 2014. Available from: <http:// www.sciencedirect.com/science/article/pii/S0301479714003351>. Acessed: Oct. 10, 2016. doi: 10.1016/j.jenvman.2014.07.003.

HULSHOFF POL, L.W. et al. Anaerobic sludge granulation. Water Research, v.38, n.6, p.1376-1389, 2004. Available from: <http:// www.sciencedirect.com/science/article/pii/S0043135403006705>. Acssessed: Nov. 07, 2016. doi: 10.1016/j.watres.2003.12.002.

KUGELMAN, I.J.; MCCARTY, P.L. Cation toxicity and simulation in anaerobic waste treatment. Journal Water Pollution Control Federation, v.37, p.97-166, 1965.

MINISTÉRIODAAGRICULTURAPECUÁRIAEABASTECIMENTO (MAPA). Brazilian Sugarcane, Sugar and Ethanol Production. Available from: <http://www.agricultura.gov.br/assuntos/sustentabilidade/ agroenergia/arquivos-precos/producao-brasileira-de-cana-de-acucaracucar-e-etanol.pdf/view>. Acssessed: Jun. 12, 2016.

MALAVOLTA, E. ABC da análise de solos e folhas: amostragem, interpretação e sugestões de adubação. São Paulo: Agronômica Ceres, 1992. 124p.

MORAES, B.S. et al. Anaerobic digestion of vinasse from sugarcane biorefineries in Brazil from energy, environmental, and economic perspectives: Profit or expense?. Applied Energy, v.113, p.825-835, 2014. Available from: <http://www.sciencedirect.com/ science/article/pii/S0306261913005849>. Acssessed: Nov. 12, 2016. doi: 10.1016/j.apenergy.2013.07.018.

OLIVEIRA-JUNIOR, V. et al. Use of dolomite limestone for acidogenic phase stabilisation on the anaerobic digestion of cane juice vinasse. In: INTERNATIONAL CONFERENCE ON ENGINEERING FOR WASTE AND BIOMASS VALORIZATION, 4., 2012, Porto, Campus Jarlard. Proceedings... Jarlard: Springer, 2012. V.4, p.152-153.

PIRES, J.F. et al. Mixed yeasts inocula for simultaneous production of SCP and treatment of vinasse to reduce soil and fresh water pollution. Journal of Environmental Management, v.182, p.455-463, 2016. Available from: <http://www.sciencedirect.com/ science/article/pii/S0301479716305436>. Acssessed: Sept. 13, 2016. doi: 10.1016/j.jenvman.2016.08.006.

RAU, G.H. et al. Reducing energy-related CO2 emissions using accelerated weathering of limestone. Energy, v.32, n.8, p.1471147, 2007. Available from: <http://www.sciencedirect.com/science/ article/pii/S0360544206002982>. Acssessed: Sept. 10, 2016. doi: 10.1016/j.energy.2006.10.011.

RIBAS, M.M.F.etal.Use of cassavawastewatertreatedanaerobically with alkaline agents as fertilizer for maize (Zea mays L.). Brazilian Archives of Biology and Technology, v.53, n.1, p.55-62, 2010. Available from: $<$ http://www.scielo.br/scielo.php?script=sci_artte xt\&pid=S1516-89132010000100007>. Acssessed: Out. 15, 2016. doi: 10.1590/S1516-89132010000100007.

RIBAS, M.M.F.; CEREDA, M.P. Stabilization of cassava wastewater during acidogenic phase in anaerobic reactor with sodium hydroxide and two sizes of dolomitic limestone. Journal of Root Crops, v.29, n.2, p.1-6, 2003.

RITTMAN, B.; MCCARTY, P. Environmental biotechnology: principles and applications. Boston: McGraw-Hill, 2001. 112p. 
SILVA, M.A.S. et al. Use of stillage and its impact on soil properties and groundwater. Revista Brasileira de Engenharia Agrícola e Ambiental, v.11, n.1, p.108-114, 2007. Available from: <http://www. scielo.br/pdf/rbeaa/v11n1/v11n1a14>. Acessed: Sept. 22, 2016.

STATSOFT INC. Statistica data analysis software system Version 7.0. Tulsa, 2008.

SUN, B. et al. Effect of particle size in a limestone-hydrochloric acid reaction system. Journal Hazard Mater, v.179, n.1-3, p.400-408, 2010. Available from: <http://www.sciencedirect. com/science/article/pii/S0304389410003249>. Acessed: Sept. 05, 2016. doi: 10.1016/j.jhazmat.2010.03.018.

TORRES, P.T.L. et al. Selección de acondicionadores químicos para el tratamiento anaerobio de aguas residuales del proceso de extracción de almidón de yuca. Revista de Ingeniería de Recursos Naturales y del Ambiente, n.7, p.10, 2008. Available from: <http://www.redalyc.org/pdf/2311/231116372008.pdf>. Acessed: Nov. 01, 2016.

YU, H.Q. et al. The roles of calcium in sludge granulation during UASB reactor start-up. Water Research, v.35, n.4, p.1052-1060, 2001. Available from: <http://www.sciencedirect.com/science/ article/pii/S0043135400003456>. Acessed: Sept. 25, 2016. doi: 10.1016/S0043-1354(00)00345-6.

ZOUTBERG, G.R.; EKER, Z. Anaerobic treatment of potato processing wastewater. Water Science and Technology, v.40, n.1, p.297304, 1999. Available from: <http://www.sciencedirect.com/ science/article/pii/S0273122399003984>. Acessed: Nov. 28, 2016. doi: 10.1016/S0273-1223(99)00398-4. 